\title{
Analysis and Evaluation of the Beijing Metro Project Financing Reforms
}

\author{
Haibin Zhao ${ }^{1, a}$, Bingjie Ren ${ }^{2, b}$, Ting Wang ${ }^{3, c}$ \\ ${ }^{1}$ Ministry of Transport Research Institute, Chaoyang, Beijing, China,100029; \\ ${ }^{2}$ Beijing Urban Construction Design \& Development Group Co., Limited, Xicheng, \\ Beijing, China, 100037;
}

\author{
${ }^{3}$ School of Civil Engineering, Beijing Jiaotong University, Haidian, Beijing, China, 100044. \\ a358608288@qq.com, b309826083@qq.com, ctingwang@bjtu.edu.cn
}

\begin{abstract}
Keywords: metro; financing; marketisation; reform
Abstract. The construction and operation of a metro system are costly, and the sustainable development of a metro system is difficult using government funding alone, particularly for developing countries. The main source for metro system financing in China is, currently, government budget and bank debt. Many cities have begun to seek new ways to attract funds from finance markets, which is increasing the need for the evaluation of metro financing. This study uses Beijing as a case study that utilises various financing modes with impressive results. As participants of the financing reform, the authors collected all the relative government documents and interviewed stakeholders to accomplish this work. This article reviews the development of financing modes for the Beijing Metro system during the last four decades and analyses the role of the government in the reformed financing system within the Chinese social political environment. The study addresses the advantages and challenges of the reforms in this context. To further analyses the technical processes of typical financing modes, the public-private partnership mode of Line 4, the BT mode of Olympic Branch Line, the insurance claim mode of Line 10 and the failure of the market oriented financing for Capital Airport Line are analysed and evaluated in detail. It concludes that the financing reform of public infrastructure in a public-ownership-dominated economy could be effective through government directions but the reformed financing is not completely market financing as shown, and the sustainability of financing will be challenging in the future.
\end{abstract}

\section{Introduction}

As private car ownership in Chinese metropolises continues to increase, traffic congestion is a major concern. China has constructed extensive metro systems in an effort to address traffic problems over the past decade. By the end of 2013, a total of 83 lines were in service in 19 mainland China cities, with a total route length of 2,476 km. Another 15 cities are building their first metro lines, with a route length of over $2400 \mathrm{~km}$ in construction. There are over 54 cities with constructed or planned metro systems, and the route length is estimated to reach $15000 \mathrm{~km}$ [1]. Such extensive metro network construction requires substantial capital. Currently, the average cost of metro transport in China is 0.6 to 0.9 billion CNY per kilometre [2,3], and the investment budget of Beijing Subway Line 16 reached 1.24 billion CNY per kilometre [4]. Reliance on government finance funds for short-term metro development and long-term operating subsidies is a financial burden, even for Beijing, fiscal revenue of which reached 366 billion [5]. A total of 297.8 billion CNY investment for future planning lines [6] and annual operating subsidies of almost 4 billion CNY remain significant financial concerns [5]. Therefore, the government has sought new financing channels and attempts to attract social capital to promote investment diversification and sustainability are apparent.

Major cities worldwide have accumulated metro construction experience in efforts to address traffic congestion. European countries mainly use the 'integration' mode of investment [7], for which the government public service institutions or state-owned public enterprises manage the investment, construction, and operation of metro projects under transparent regulatory conditions. For cities such as London, New York, and Paris, metro project construction and operation investment funds have been subsidised by central and local governments at all levels, with slight differences in allocation 
proportions. Metro investment modes in Asian countries are different from those of European countries. The Singapore government finances SMRT exclusively but it is operated by the private sector. Kuala Lumpur Light Rail Line 1 implemented the BOT and land development mode. Bangkok elevated railway carried out a simple BOT mode [8]. Tokyo Metro lines were divided into public and private lines because of the formation of distinct metro construction financing modes. For private metro line construction, the government provided a certain percentage of loans with discounted interest to private entities, whereas for public metro lines, funding mainly originated from government budget and commercial loans [9].

Metro financing modes depend on the funding provider, the financing method, and the entity that retains the operating rights after completion. Financing modes determine the responsibilities and rights of project investors including investment distribution, function orientation, design criteria, project construction management, and operation strategy. Therefore, financing modes significantly affect cost control management activity and effect and service level promotion. Some researchers showed that the main problems associated with urban infrastructure financing are inefficiency and institutional deficiencies [10]. The majority of Western researchers consider that construction of capital-intensive projects in China is often quick and efficient because of the political circumstances. However, government power is not as concentrated as first thought. Groenleer et al. [11] analysed decision-making processes on major Chinese engineering projects and explained why some projects' decision-making processes take longer than expected. Becky et al. [12] suggested that the Chinese government faces three obstacles with respect to metro construction: technology, financing, and the ability to repay debt. The World Bank and the National Development and Reform Commission of China [13] attempted to maximise minimum investments in metro systems. However, investment in metro construction is substantial, and the majority of metro projects mainly adopt debt financing. Tsui [14] found that infrastructure investment resulted in increases in local debt in most cases. Zheng [15] studied the Beijing Metro financing model and analysed the financial pressure experienced by the government. The author stated that current financing mode sustainability was crucial during large-scale metro construction. Dalvi [16] addressed the private sector financing mode of the Bombay metro construction and claimed that attracting private capital to metro construction can alleviate financial pressure and spread risk. Various financing modes are currently used for capital-intensive infrastructure development worldwide, among which public-private-partnerships (PPPs) have been adopted by some authorities. PPP modes can raise private funds effectively but lack the flexibility to cater to changes in the external environment [17]. Zheng [15] analysed the PPP mode assumed by Line 4 of the Beijing Metro. The result demonstrated that the PPP mode reduced investment, facilitated only by a perfect regulatory-based framework. According to long-term practices, some common implementing principles and critical elements were extracted to provide the basis for PPP success $[18,19,20]$.

The Chinese social and economy is different from that of most countries, so the capital-intensive project financing reform in China was seldom evaluated in existing research, especially from the social system perspective. Many metropolises in China are currently exploring metro financing reform under the Chinese political system using foreign capital-intensive project financing experience for reference. This work concentrates on Beijing, which has conducted various attempts in this field and developed successful new financing modes. The remainder of the article is structured as following. Firstly, the development of metro financing in Beijing is summarized, and then the advantages and drawbacks of the financing reform were evaluated, and more detailed assessments are promoted by case study. Finally, the conclusions and recommendations are presented. In the early stage of metro construction, the government provided exclusive funding and later applied debt financing with proprietary government funds when more lines were built. In the past decade, Beijing conducted substantial framework reform for metro investment and launched debt-type financing innovations and equity-type financing that surpassed all other metro financing in China. These attempts provide precedents for other domestic metro financing and could benefit the practices of other developing countries. 


\section{The Development and Evolution of The Beijing Metro's Financing Mode}

Beijing's metro financing reform is linked to metro construction and development. This section summarises and analyses the financing mode transformation process of the Beijing Metro, and evaluates the financing characteristics at various stages combining the construction history with the mid- to long-term development planning.

\section{Construction and planning of the Beijing metro}

As the first metro system in mainland China, the Beijing Metro system development is classified into four stages: the strategic reserve stage, the primary development stage, the Olympics stage, and the rapid progress stage. In the strategic reserve stage, prior to 1971, $23.6 \mathrm{~km}$ of metro line with 17 stations was built, which was based on military considerations and was open for citizens years later. The primary development stage lasted from 1984 to 2000, during which the Beijing Metro construction stagnated for an extended period. Only two lines covering $54 \mathrm{~km}$ were built with 1.185 million passengers transported per day. The Olympic stage commenced with Beijing winning the bid to host the 29th summer Olympic Games in 2001, which accelerated plans to expand the metro network. In the summer of 2008, four new lines: Line 5, the first phase of Line 10, the Olympic Branch Line and the Airport Express opened on July 19, forming a network of eight lines with a route length of $198 \mathrm{~km}$ and a daily ridership of 3.5 million. The Beijing Metro system has undergone rapid expansion since the end of the Olympic Games. New lines begin operating almost every year. Currently, the Beijing Metro consists of $465 \mathrm{~km}$ serving 277 stations. The average daily patronage has increased to 10 million.

The long-term network scale has surpassed that of most countries after several revisions. In November 2012, The National Development and Reform Commission approved 'The short-term construction plan adjustment of the Beijing Metro (2007 to 2016)'. The plan added four lines: Shanhou Line (Phase 3 of Line 8), Line 16, Yanfang Line, and New Airport Express. The planned metro network will include 25 lines totalling $703 \mathrm{~km}$ by the end of 2016 and is expected to further expand to $1000 \mathrm{~km}$ in the long term.

\section{The evolution of metro financing in Beijing}

The financing mode of the Beijing Metro has seen continuous innovation development. The characteristics of the planned economy shaped the early financing and operation mode of the Beijing Metro: the government financed everything. Despite exclusive government financing, with the advantages of rapid fund raising and low costs, the financial burden compounded the budget problem. The Beijing Metro system, therefore, began to adopt improved financing modes. Since 2002, the Beijing Metro project has adopted a new financing mode whereby the total investment is composed of 40 percent municipal and district financial funds (provided by the districts that the line covers) and 60 percent bank loans. With respect to the bank loans, targeting social capital reduces bank loans and the financial burden on the government. Therefore, in 2001, the Beijing municipal government changed the Beijing Subway Corporation to the Beijing Subway Limited Liability Company to develop new financing modes to draw social capital. In 2003, the Beijing Subway Company was further restructured and the original managing company became three separate entities: Beijing Infrastructure Investment Corporation, Beijing Rail Transit Construction and Management Corporation, and Beijing Subway Operation Corporation in 2003. The Beijing Infrastructure Investment Corporation was mainly responsible for metro financing and became a professional entity implementing financing marketisation on behalf of the government. The history of the construction and operation of the Beijing Metro demonstrates incremental experience in financing mode changes: government financial investment under a planned economy, government-sponsored debt financing, multiparty financing, and joint stock financing. The main modes can be categorised as total fiscal financing mode, government-dominated debt financing mode, and diversified financing mode.

\section{Total fiscal financing mode}

During early metro construction, the Beijing government sponsored the design, construction, and operation exclusively. The central government financed Lines 1 and 2. This mode included no interest payments and the financial cost was omitted. However, the financial fund was limited; it is 
unsustainable to develop capital-intensive projects that rely wholly on government funds. Additionally, a lack of effective incentive mechanisms causes low levels of operational efficiency and service.

\section{Government-dominated debt financing mode}

The metro construction funds under the government-dominated financing mode are provided by the municipal government, banks, and foreign institutions such as metro equipment suppliers. The government invests a portion of the funds, and banks or bond issuance provides the remainder to the metro company with the credibility of the government. As for Beijing, the government provided $40 \%$ of total funds, and the rest $60 \%$ were raised by debt. Before 2007 , the government funds were totally from the municipal government, and after 2007, these funds were shared by the municipal government and district government by 8:2 according to the new policy. If the line covers more than one district, the district funds will be allocated by the line length in each district. The fund sharing of districts before 2015 is presented in Table 1.

Table 1 District shares of total investment (billion CNY)

\begin{tabular}{cccc}
\hline Metro line & Changyang District & Fengtai District & Haidian District \\
\hline Daxing & - & 105.58 & - \\
Yizhuang & 6.4 .1 & 33.31 & - \\
Fangshan & - & 116.08 & - \\
Changping phase 1 & - & - & 63.03 \\
West Suburban & - & - & 79.97 \\
9 & - & 344.81 & 178.79 \\
10 & 85.43 & 478.14 & 239.94 \\
6 phase 1 & 388.97 & - & 124.83 \\
15 phase 1 & 578.36 & - & - \\
8 phase 2 & 110.42 & - & 85.63 \\
7 & 100.55 & 8.38 & - \\
14 & 161.06 & 152.43 & - \\
Toal & 1488.85 & 1238.74 & 772.19 \\
\hline
\end{tabular}

There are many debt-financing methods including loans, leases, bonds, and commercial credit. Inventory assets were liquidated by the sale and leaseback mode with respect to fixed assets such as trains for Line 1. Line 5 adopted export credit, and Line 10 conducted insurance claims. All of these methods are debt-financing modes. The advantages of debt financing are ease with respect to operations and availability, which can dramatically alleviate the pressures of metro construction investment on local authorities. The disadvantages of debt financing are high costs and long-term financial burden. Between 2007 and 2015, the total metro investment will be 153 billion. If all the $60 \%$ part is raised by debt, it will be 99.4 billion. The final principal and interest will be 203.8 billion. Additionally, the government manages the construction and operation and the company, on behalf of government, has no incentive to improve service quality and efficiency.

\section{Diversified financing modes}

The rapid development of the Beijing Metro causes challenges for the government in terms of providing the required funds and loans. The design, introduction, and application of capital markets instruments created new financing modes during metro construction. The PPP mode describes a class of financing modes that include service agreements, BT mode, and BOT mode. An innovated BOT mode (called PPP in a narrow sense) and a BT mode were applied in the construction of Line 4 and the Olympic Branch Line in Beijing, respectively. Additionally, the Beijing Metro also raised funds through various capital market instruments including enterprise bonds, short-term financing bonds, 
and medium-term notes to diversify financing channels. Specifically, innovative operation modes such as bank loan bidding and binding interest rates have been applied to bank loans. This method expands the financing channels and saves financing costs to a significant extent. Moreover, the operational efficiency and quality of service were notably improved by investors' participation in metro operations for some financing modes.

\section{The Implementation, Advantages, and Disadvantages of the Beijing Metro Financing Reform}

Whether through government direct investment or capital markets, the government under the Chinese social system dominates the financing of the Beijing Metro. Metro investment and ownership is a political rather than an economic problem because the metro represents major infrastructure which has to be dominated by public ownership. All of the innovation and financing reform in this sector is conducted according to this premise. The following section summarises the advantages and the existing problems in the Chinese political and economic context based on an analysis of the implementation mechanism of the Beijing Metro financing reform.

The implementation of the government-led financing reform

In China, government action plays a significant role in the economy, particularly with respect to capital-intensive infrastructure. Therefore, during the transition from exclusive government financing to marketised financing, the government played a leading policy-making, regulatory, and implementing role. Additionally, the share-holding structure reflects the dominant public ownership. With respect to the three levels of metro financing reform: policies and regulations, the management system, and the operating mechanism, the Beijing municipal government provided the direction, scale, quality, and structure of the metro financing. This 'government decide' feature is central to the implementation of the metro financing innovation campaign.

The government guides the implementation of Beijing Metro financing reform. High-level departments of the Beijing government design the policies and regulations of the metro financing reform that formulate a construction plan and investment policy. For each metro line, the government issued and managed regulations, detailed construction plans, urban construction, acquisition, capital, bidding, equipment purchase, specific financing mode, and tax incentives. Specifically, Beijing Infrastructure Investment Corporation, Beijing Rail Transit Construction and Management Corporation, and Beijing Subway Operation Corporation are all state-owned corporations funded by the State-owned Assets Supervision and Administration Commission, and these companies are responsible for the metro project investment, construction, and operation, respectively. The three corporations have political hierarchies that correspond to the government administrative levels, and they operate under the supervision of the Beijing municipal government. The government originally assumed financing but it is now the responsibility of the enterprise controlled by the government, which is Beijing Infrastructure Investment Corporation. This entity focuses on the financing, investment, management, capital operation, capital preservation, and appreciation functions on behalf of the government. The combination of government policy making and the Beijing Infrastructure Investment Corporation formed the government-led financing reform system with the characteristics of municipal and district joint building, multi-stakeholder participation, and multi-channel financing.

\section{Advantages and disadvantages of the Beijing Metro financing reform}

The government-led financing reform in Beijing derives benefits from the Chinese political and economic system, in which state-owned corporations dominate the economy. Financing from public-owned entities is efficient and low-cost. However, these characteristics also suffer some drawbacks concerning reforms.

\section{Advantages}

First, raising funds from state-owned companies, such as banks, facilitated remarkable reform achievements in a short period. Over ten new financing modes have been launched, and over 100 billion CNY in financing was obtained over a decade beginning in the year 2000 when Beijing initiated metro financing reform. Traditional administrative economy dynamics influenced the 
success of the financing reform. Government documents guided the majority of the cooperation between the metro company and the state-owned finance suppliers of the Beijing Municipal Commission of Development and Reform; thus, negotiation costs were low.

Second, this characteristic ensures implementation stability. The government formulated the financing laws and norms and the corresponding financing, investment, construction, and operations systems. This framework established the financing platform and operation mechanisms. The aggressive government provided a stable policy environment for Beijing Metro financing innovation. The functional Beijing municipal government departments led the overall investment and financing reform, construction, and operation process for the Beijing Metro. However, the operation is not under the direct command of the government but is conducted by the corporation founded by the government. Beijing succeeded in achieving breakthrough reforms of the investment system, construction system, and operation system in a stable policy and operations environment by absorbing bulk social capital to retain the sustainable development of the Beijing Metro.

Finally, in a public ownership-dominated political and economic environment, abundant funds are available for public infrastructure construction financing. The metro investment company is state-owned, controlled by the government, and can attract capital for substantial infrastructure development because of the government's credit and fiscal support. The common ownership of the metro company and finance suppliers provides a natural basis for capital cooperation and facilitates fund raising. With respect to the sale and lease back mode applied in Line 1, the Industrial and Commercial Bank of China and its leasing company spent 8 billion CNY in the purchase of vehicles and other operating equipment and then renting them to the metro company. These two companies are both financial powerhouses owned by the state. This mode was arranged and implemented effectively by the Beijing Municipal Commission of Development and Reform. A reliance on private capital could not have yielded such substantial funds in a short time, and implementation processes would have encountered certain obstacles.

\section{Disadvantages}

There are also obvious flaws in this rapid financing reform dominated by administrative command.

First, the new finance structure is still a result of public capital cooperation with a small amount of private capital. The financing process is represented by a public capital operation under government control, not the result of free market competition. Therefore, the Beijing Metro financing reform is still not market-oriented because of inadequate competition. Currently, over $80 \%$ of the overall capital raised for metro construction originated from state-owned corporations. The metro company has a low rate of return or continued losses without fiscal subsidy, and it is difficult to attract profit-driven private capital. Although the financing reform can currently achieve instant success because of administrative commands, the realisation of the return of this round of financing will challenge this dynamic in the future.

Second, even for the PPP financing modes, the metro operation companies remain state-owned corporations or state-capital-holding companies. Thus, the metro company does not have independent rights to operating decisions and has little incentive to control operation cost and boost service levels. No one is responsible for company losses, and substantial subsidies are required from the government. The Beijing Metro is considered as political infrastructure; the government controls the fare policy and service times. Even if market financing is adopted, the main operating decisions will still be under the purview of the government and the operation company will not represent an independent market entity, which deviates from one of the initial objectives of the financing reform. Although MTR Corporation from Hong Kong represents a private investor of the PPP mode for Beijing Metro Line 4 and has owned the franchise for 30 years, the corporation does not own the right of independent pricing. The fares for Line 4 are consistent with the Beijing Metro network. The administrative features of the Beijing metro operation are more obvious, and all the senior managers are appointed by the government. The metro's operation subsidy was up to 4 billion CNY in 2013. Governments cannot determine the causes of the metro operating company losses. It is difficult to ascertain to what extent low fares or inefficient management is to blame. The corporation also has no incentive to 
improve service levels. If private capital is introduced to metro, the stakeholders will strive for profits through cost control and boost income. The case analysis of Line 4 illustrates this factor.

\section{Case Analysis}

\section{The PPP mode of Line 4}

Beijing Metro Line 4 is the trunk line of the Beijing's Metro network. The line covers $28.2 \mathrm{~km}$ and serves 24 stations with a total investment of approximately 15.3 billion CNY.

The Beijing Metro Line 4 employs a PPP financing mode to seek additional finance, control construction costs, and introduce a competition mechanism into metro operations. The implementation process is shown in Fig. 1. The construction project is divided into two parts. Part A, which represents government investment, covers the cost of civil engineering. The total investment is 10.7 billion CNY, which accounts for $70 \%$ of the total. Part B covers the cost of mechanical and electrical equipment such as vehicles and signals. The investment is 4.6 billion, $30 \%$ of the total. This portion of the capital is provided by MTR Corporation, Beijing Capital Group, and Beijing Infrastructure Investment Corporation. The three entities formed a consortium that is responsible for investment. When the construction work is completed, a company co-organised by the consortium will be franchised to operate Line 4 . When the franchise term expires, the company will transfer all facilities in good condition for no charge.

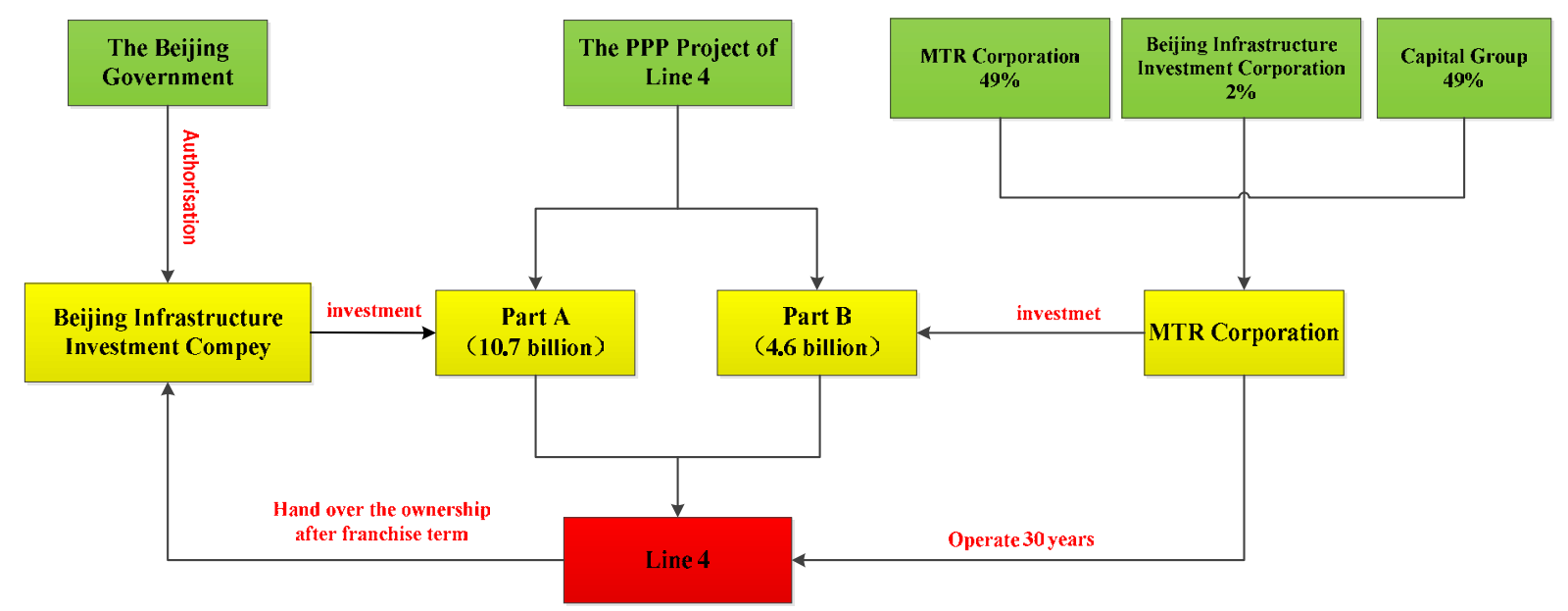

Fig. 1 The implementation process of the PPP mode for Line 4

Beijing Metro Line 4 is the first metro project in mainland China utilising foreign capital and introducing the private sector to operations. The private sector contributed approximately 4.6 billion CNY, which relieved the government's financial burden. Additionally, the PPP increases stakeholder incentive to control costs and reduce the risk of construction fund overruns. The PPP mode reduced fiscal expenses by 9.88 billion CNY, including investment and operation subsidies, for the whole franchise operation cycle. The cooperation protocol effectively allocates risk. If the real demand is $10 \%$ less than predicted passenger flow, the PPP mode can save an additional 1.94 billion CNY in government expenses compared to traditional debt financing approaches. Franchise companies also have an incentive to improve service quality and operating efficiency to attract patronage. The company reduced maintenance costs from the predicted amount of 90 million to 33 million CNY in 2010 through management strategy [15] to increase profits. Moreover, company managers are responsible for seeking profits for the private stakeholders. This is reflected by the advertising income; the franchise company gained half of the Beijing Subway Operation Corporation's advertising income albeit the Beijing Subway Operation Corporation runs ten times more route length. 


\section{The BT mode of the Olympic Branch Line}

The Olympic Line is a key public infrastructure project that supported the 2008 Olympic Games. The line covers $4.7 \mathrm{~km}$ and serves four stations. The total investment is 2.42 billion CNY (excluding the engineering work of Beitucheng station).

The investment of the Olympic Branch Line was part BT and part non-BT by a ratio of seven to three. The main portion of the BT project is composed of civil engineering segments, the stations, and the mechanical and electrical equipment engineering of stations. The original budget is approximately 1.56 billion CNY. The project company, Beijing Metro Line 10 Investment Corporation was founded and holds the responsibility for the bidding of this BT project. Finally, the consortiums comprised of China Railway Group Limited, China Railway Electrification Bureau Group, and China Railway No. 3 Engineering Group were awarded the BT project with 1.095 billion CNY. After completion, the project company transferred the engineering to Line 10 Investment Company, which examined it according to construction standards. The investment company bought back the finished project.

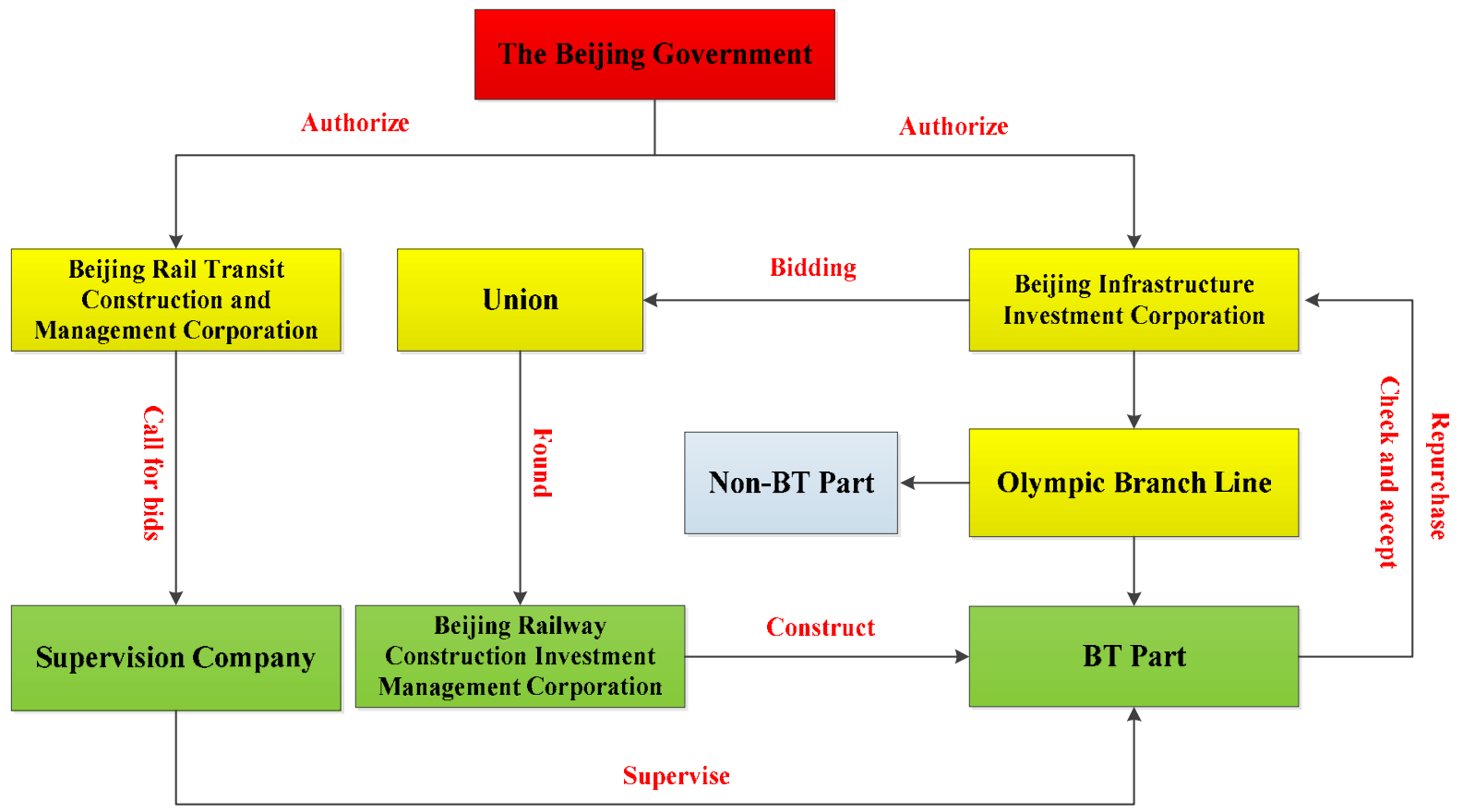

Fig. 2 Operation framework of the BT financing mode for Olympic Branch Line

This line is the first metro project financed by BT mode and is part of the infrastructure financing system reform in Beijing. The outcome demonstrated cost savings of up to 340 million CNY compared to original budget, accounting for $23.7 \%$ of the total investment. The BT mode distributes risk among government, metro owner on behalf of government and the BT company. Common problems during construction including schedule delay, failure of funds in reaching accounts were avoided because the BT company was responsible for everything. The completed project have to be go through strict inspection before transferred to the government, so the BT company strived to control the construction quality.

\section{The insurance claim financing mode of Line 10}

Metro Line 10, which covers 57.1 kilometres and serves 45 stations, is the second circle of the Beijing's metro system. Insurance funding was introduced to Beijing infrastructure construction for the first time as one of the financing modes for this project.

The insurance bond-financing mode of Metro Line 10 was conducted by Beijing Infrastructure Investment Corporation, everal insurance institutions, Pacific Investment Management Corporation (PIMC), and the Industrial and Commercial Bank of China (ICBC). The insurance institution commissioned PIMC to sign an investment agreement for Metro Line 10 with Beijing Infrastructure Investment Corporation. The agreement determined the amount of debt investment, which was three 
billion $\mathrm{CNY}$ and the interest rate was $5.07 \%$ with a seven-year term. A total of fourteen insurance agencies quickly subscribed the debt securities. The Industrial and Commercial Bank of China was responsible for cash flow during the term. Fig. 3 illustrates the operation of this mode.

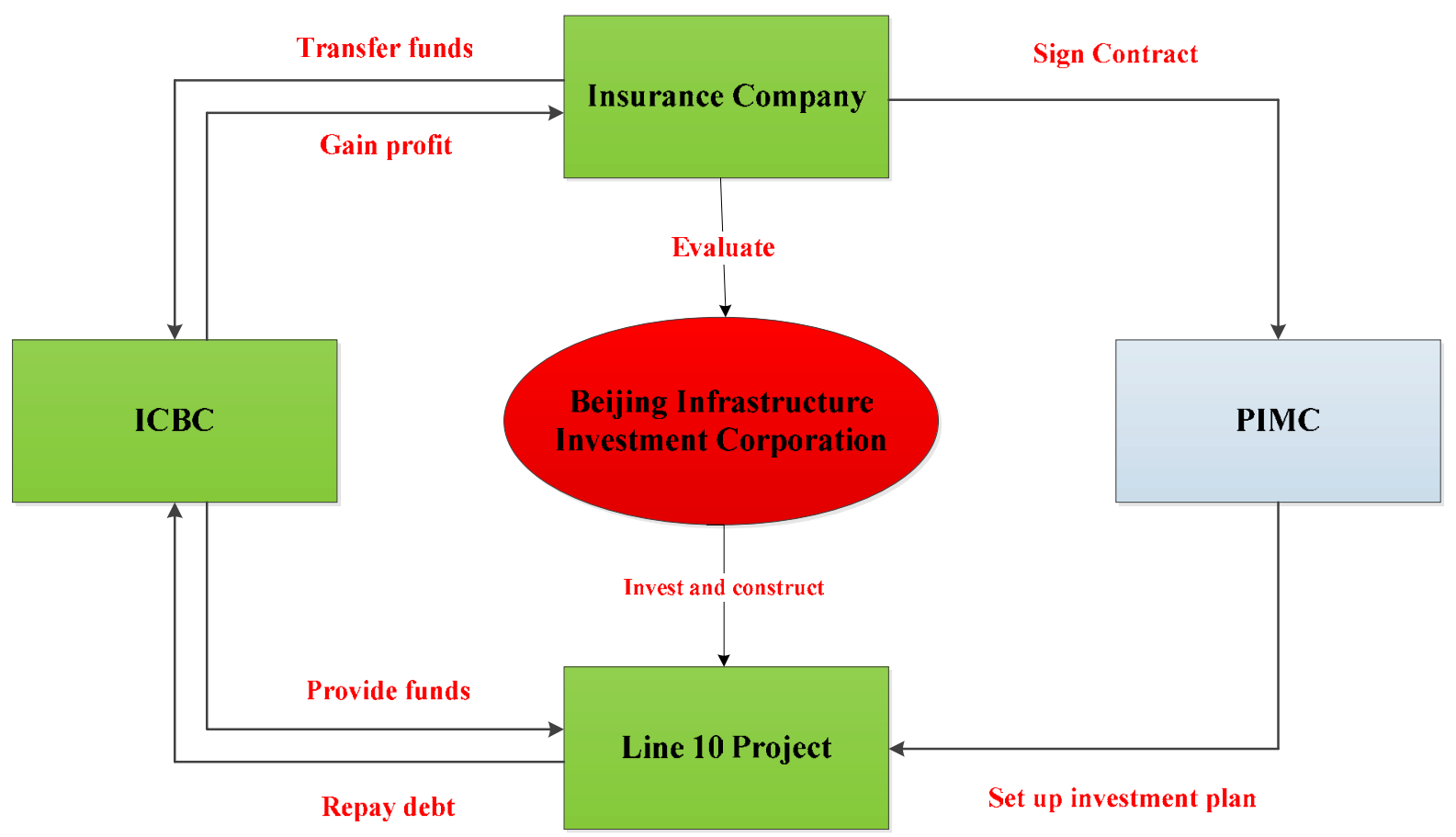

Fig. 3: The operation process of the insurance claim-financing mode

The financing of Line 10 is the first approved investment plan of insurance claims in Beijing. The government's credibility improved the attractiveness of funds, and various market players participated. The mode obtains a substantial number of insurance funds, and it can reduce the financing costs of rail transit projects by $14 \%$ compared to bank loan.

\section{The failure of the market-oriented financing for Capital Airport Line}

Capital Airport Line is the first airport rail transit in Beijing, which is from Dongzhimen to T2 and T3 terminal, serving $28 \mathrm{~km}$. It was considered that this line serves high level passengers and the fare is not capped by the low flat fare of Beijing rail network, so the expected return can attract market capital. The first round of evaluation is haste and the annual demand of this line is expected to be 24.51 billion in the long run at a fare of $32 \mathrm{CNY}$, which accounts for $41 \%$ of the design annual capacity of the airport. With a 0.5 billion subsidy from the government, the expected IIR reaches $12 \%$. Therefore, this line was financed almost totally in the capital market.

The design and implementation of the financing scheme for this line is as follows. The original budget, five billion, deducted by 0.5 billion of the government subsidy, was financed by the joint project company founded by China CREC Railway Electrification Bureau Group, Beijing Oriental Culture Group, Capital Airports Holding Company, Beijing Capital Highway Development Group and Beijing Rail Transit Construction and Management Corporation, with a holding structure presented in Fig. 4. 


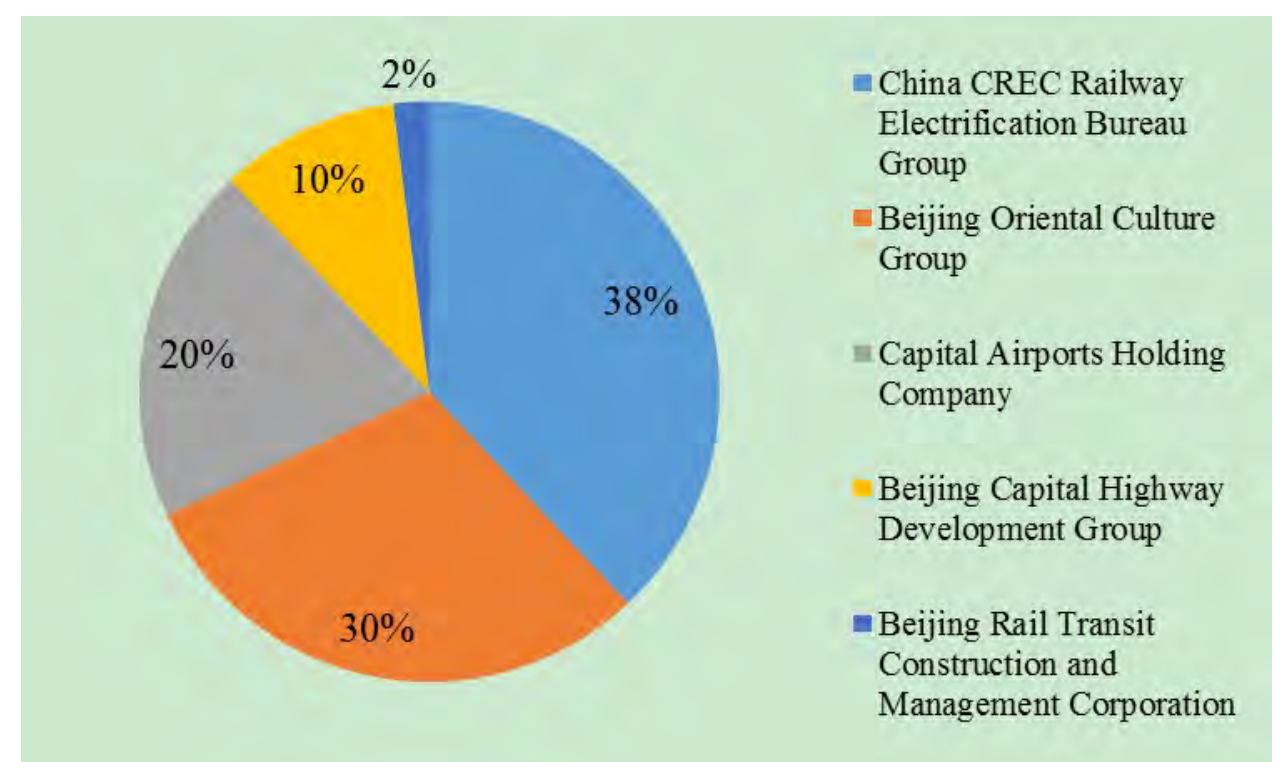

Fig. 4 Holding structure of the project company for Capital Airport Line

However, as the project proceeding, stake holders realized that the expected return probably cannot achieved. First, the total cost of this line increased to 6.5 billion due to adjustment of alignment and unexpected land compensation cost. Second, independent consulting company launched a new demand forecasting and suggested the original forecasting was too optimistic. The new forecasted annual demand was 18.99 million, accounting for $31 \%$ of the total demand of the airport, with a declination of 23\%. Third, the updated forecasting was made at a fare level of 25 CNY. Understanding this point, the participant became to reluctant to supply finance. Because this line is a supporting project of the 2008 Olympic Game, and the schedule was tight, the government had to take over the project to make sure it would be accomplish on time.

The failure of this case demonstrates that the authority should keep one point in mind for any concession project or PPP project that the market capital is profit-seeking. This is the only reason it flow into public infrastructure projects. Thus the profitability of the project should be carefully evaluated before bidding. And also, the forecasted demand is the key factor. In fact, the initial forecasting accounting for $41 \%$ of the total demand of the airport is obvious an overestimation. Such a high sharing has never been seen in any other airport rail line in the world.

\section{Conclusions and Recommendations}

During the last decade, the financing of the Beijing Metro has developed from an exclusively government invested mode into a diversified financing system, which eases the financial pressure on the government, reduces the cost of financing, establishes a competition environment, and achieves significant cost savings in metro operation. Key infrastructure financing reform in a public ownership-dominated political and economic environment has obvious characteristics. This paper summarised the evolution of the Beijing Metro financing, extracted the implementation scheme of reform, and concluded the advantages and disadvantages of public infrastructure financing reform in the Chinese economic context. Finally, three financing modes were analysed and evaluated by case study.

The evolution of the Beijing Metro financing reform is a component of China's economic reforms embodied in public infrastructure construction. The transformation of financing from a single government investment mode to a market-based diversified investment system resolves problems associated with a shortage of funds. The transformation introduces social capital to public infrastructure investment for superior management of inefficient, state-owned corporations and improves the quality of public services in the long term. The Beijing Metro has attracted more than 100 billion CNY of social funds as of the year 2012, which has addressed the problem of limited 
government financing. Beijing Metro Line 4 introduced MTR Corporation investment in the form of the PPP mode and incorporated the extensive operating experience of the corporation into Beijing Metro operations. This has created competitive pressure to encourage the state-owned operating company to boost levels of service.

Public infrastructure financing reforms conducted in a public ownership-based economic environment have the advantage of low operation costs and high execution efficiency, but problems such as a low level of marketisation and obvious administrative interventions cannot be ignored. Financing reform of the Beijing Metro has included a variety of modes and raised substantial funds in a short period, which can be ascribed to the public companies. Government administrative command ensures efficient implementation. Moreover, the metro project as a public good obtains financing from publicly owned banks and other public entities. However, this advantage has caused problems. Under administrative command, with state-owned corporation participation, the financing reform is not as marketised as it appears, and whether the new financing system is sustainable remains to be seen. State-held corporations still operate the metro. The effective implementation of financing reform goals to enhance operation efficiency, improve service quality, and reduce operation costs is difficult.

As the leader in metro construction, the government should provide an effective legal and regulatory framework for the metro financing system, which regulates participant behaviour to ensure efficient financing. However, currently, the financing system still lacks practical legal protection and fiscal policy. Effective financing and compensation mechanisms rely on government regulation. The government must improve the standard of regulatory documents, clarify regulatory content, cast strict regulation on business projects and bidding management, and clearly define investor qualifications.

The current financing mode still represents government activity. Fiscal funds still form the majority of the capital supply for metro construction. Financing channels must be extended. Financing reform must solve the problem of funds and reduce cost, improve efficiency, and fully exploit the metro project's own business resources. Joint development of the metro project and peripheral land by the introduction of a business development model would significantly increase land value. The land development can provide metro patronage and, more importantly, the metro company can enjoy external benefits that will increase the profitability of metro projects and attract investors. When land is not available, funding via the property taxes on the real estate can be an alternative approach [21].

\section{Acknowledgements}

This work is supported by the National Natural Science Foundation of China (Grant No. 51408029). Beijing Infrastructure Investment Corporation Limited, Beijing Subway Operation Corporation Limited and Beijing MTR Corporation Limited were thanked for providing raw data, project documents and interview.

\section{References}

[1] China Metro Annual Report Team. (2013).“2013Annual Report of China Urban Mass Transit.” China Railway Press, Beijing.(In Chinese).

[2] Chen, F., Wang. Z.J. (2007).“metro construction cost analysis.” Railway Transport and Economy., 30(9),53-55. (In Chinese)

[3] Zheng, C.(2014)."Financing new metros-The Beijing metro financing sustainability study.”Transport Policy.,32.148-155. (In Chinese)

[4] Chinese News Web. (2012). "Simplify the new-built metro, Construct energy saving urban rail transit." <http://news.xinhua08.com/a/20120312/919513.shtml>(Aug.5,2014) 
[5] Finance Bureau of Beijing (FBB). ( 2014). "Report on budget execution of 2013 and budget draft of 2014 of Beijing."

[6] Zhang, G., Liu, Y., and Xu, X. ( 2012). "Innovation of investment and financing theory and practice of Beijing urban rail transit. "Tsing Hua University Press, Beijing (In Chinese).

[7] Stopher,P.R.(1993).“Financing urban rail projects: The case of Los Angeles.’Transportation.,20(3), 43-50.

[8] Chen, S. Z.(1996). "inspiration of metro transit system development in Bangkok, Kuala Lumpur, Manila,.’Urban Rapid Rail Transit, 1,6-10.(In Chinese)

[9] Wang, Y.(2007). "Tokyo metro construction financing system analysis." Japanese Studies,5,96-107. (In Chinese)

[10]Wu, W. P.(1999). "Reforming China's institutional environment for urban infrastructure provision.”Urban Stud.,26 (13), 2263-2282. (In Chinese)

[11] Groenleer, M., Jiang, T.T. (2012). "Applying Western decision-making theory to the study of transport infrastructure development in China: The case of the Harbin metro." Policy and Society.,31(1), 73-85

[12] Becky, P. Y. LOO., Dennis, Y. N. LI. (2006). "Developing metro systems in the People's Republic of China:Policy and gaps.’Transportation.,33(2),115-132.

[13] The World Bank and the National Development and Reform Commission (NDRC). (2010). Urban Rail Development in China: Prospects, Issues and Options, World Bank Documents \& Reports No. 55772.

[14] Tsui, Kai Yuen. (2011). “China's infrastructure investment boom and local debt crisis.” Eurasian Geogr. Econ. ,52 (5), 686-711.

[15]Zheng, C.(2013)."Public-private partnerships in China: A case of the Beijing No.4 Metro line.'Transport Policy.,30,153-160.(In Chinese)

[16] Dalvi, M. Q. (1999). "Financing a metro rail through private sector initiative: The Mumbai Metro.” Transport Reviews: A Transnational Transdisciplinary Journal., 19(2), 141-156.

[17] Siemiatycki, M. (2009). "Delivering transportation infrastructure through public-private partnerships : Planning Concerns.” Journal of the American Planning Association.,76 (1).43-58.

[18]Zhang, X.Q. (2005). “Critical success factors for public-private partnerships in infrastructure development.”Journal of Construction Engineering and Management.,131 (1),3-14(In Chinese).

[19] Garvin, M.J., Bosso, D. (2008). “Assessing the effectiveness of infrastructure public-private partnership programs and projects.” Public Works Management \& Policy.,13(2), 162-178.

[20] Aziz, A. M. A. (2007). "Successful delivery of public-private partnerships for infrastructure development.” Journal of Construction Engineering and Management.,21(6), 918-931.

[21] Oña J., Calvo F. J., Garach L., Oña R. and López G.(2010). "How to Expand Subway and Urban Railway Networks." Transportation Research Record: Journal of the Transportation Research Board, 2146, 10-17 